\title{
COMMUNICATIVE SOCIAL INTERACTIONS AS AN EFFORT TO PREVENT RADICAL ISLAM IN STUDENTS
}

\section{Ida Umami}

State Islamic Institute Metro

Iringmulyo, Metro, Lampung Indonesia, 34112

E-mail: idaumami.iainmetro@gmail.com

\begin{tabular}{|c|c|c|}
\hline Received: & Revised: & Approved: \\
$06 / 06 / 2020$ & $25 / 06 / 2020$ & $30 / 06 / 2020$ \\
\hline
\end{tabular}

DOI: https:// doi.org/10.32332/akademika.v25i1.2154

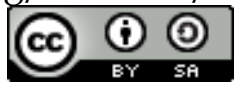

Communicative social interactions as a radical Islamic prevention effort in students of Licensed Under a Creative Commons Attribution-

ShareAlike 4.0 International License

\begin{abstract}
This paper discusses the prevention efforts of radical understanding among students through communicative social interactions. This study is a literature study with a psychological approach. Data Research Methods use Library research derived from the literature, research results and various scientific articles and books collected with documentation techniques. The collected data is then analyzed using the content analysis method. This method is operationalized by making inferences - the inferences that can be imitated and valid for data by observing the context. The results of this research are social interactions are indispensable in student life as individuals and community members so communicate and assist and cooperate in achieving common goals desired. Positive social interactions will be able to be a sense of religious understanding among closed and textual students, so they feel as a group that feels most understanding of God's teachings. Therefore, there needs to be a better knowledge and understanding of religion for students and strive to conduct harmonious and communicative social interaction so that students can avoid and be prevented from understanding religious-based radicals and become a person who has a high social concern.
\end{abstract}

Keywords: Communicative Social Interactions, Prevention, Radical Islam, Colleges 


\section{A. Introduction}

Prevention of radical understanding through the means of interactive communication is an alternative option with a psychological approach that can be done in college student groups. The education institute is by far the most effective area of the nursery and the spread of religious radicalism. Indonesia National Counter-Terrorism Agency Research in 2012 against 110 perpetrators of terrorism has been signaling the potential of radicalism among students. ${ }^{1}$ The Indonesia National Counter-Terrorism Agency syndications were confirmed by some of the growing research of radicalism in universities. ${ }^{2}$ Even the 2017 Indonesia National Counter-Terrorism Agency re-affirmed its findings that 39\% of students in 15 colleges were attracted to radical organizations who wanted to replace state ideology. ${ }^{3}$ Related to these findings, one way to tackle radicalism is to focus on prevention programs in education institutions.

The study on the handling of radicalism in Indonesia has so far been mapped to two strategies: counter-attack and deradicalization (soft approach). The strategy and approach of the soft approach through this deradicalization consists of two kinds that are explicit that directly targets the counter ideology of violence held by actors. The second way is implicit deradicalization that sneaks into the needs of emotion and psychological perpetrators. The implicit deradicalization effort provides the expertise courses and family engagement that enable the perpetrator to easily reintegrate to the community. 4 The tendency of radicalism studies focuses more on the issues of combating understanding and radical movement. 5

1 Arbi Sumandoyo, “Gelombang Stigmatisasi 'Radikalisme' di Perguruan Timnggi Negeri, dikutip dari https://tirto.id/gelombang-stigmatisasiradikalisme-di-perguruan-tinggi-negeri-cPq7.

2 Saifudin, "Radikalisme Islam di Kalangan Mahasiswa (sebuah Metamorfosa Baru)", dalam ANALISIS, Vol XI, Nomor 1, 2011, h. 17-32. Aseri, Akh. Fauzi, "Radikalisme Islam di Kalangan Mahasiswa Perguruan Tinggi Negeri Banjarmasin", dalam TASHWIR: Jurnal Penelitian Agama dan Sosial Budaya, Vol 3. No. 6, 2015.

3 Sumandoyo, "Gelombang Stigmatisasi", dikutip dari https://tirto.id/gelombang-stigmatisasi-radikalisme-di-perguruan-tinggi-negericPq7.

4 Arie W. Kruglanski dkk., "The Psychology of Radicalization and Deradicalization: How Significance Quest Impacts Violent Extremism: Processes of Radicalization and Deradicalization," Political Psychology 35 (Februari 2014): 88, https://doi.org/10.1111/pops.12163.

5 Abu Rokhmad, "Radikalisme Islam dan Upaya Deradikalisasi Paham Radikal," Walisongo: Jurnal Penelitian Sosial Keagamaan 20, no. 1 (30 Mei 2012): 79, https://doi.org/10.21580/ws.20.1.185. Petrus Reinhard Golose, Deradikalisasi 
The study of the prevention of radicalism tends to target the planting of moderate ideologies and multiculturalism as counter-radicalism. ${ }^{6}$ While psychological aspects of communication not yet much exploration adequately.

Therefore, this paper intends to fill the void of radical understanding prevention studies among students through communicative social interactions. This study is important, considering that the most commonplace tools used for radical propagation are direct communication, mass media, educational institutions, and family relationships. Thus the argument built in this paper is an interactive communication line to be an effective medium to stem and prevent the spread of radical ideology among students.

\section{B. Literature Review}

1. The Concept Of Communicative Social Interaction

As social beings that cannot live alone, interaction with other human beings is a fundamental essential for a human being to get help from his neighbor. Through interactions, there will be feedback between human beings in the lives of everyday life. Hence the term social interaction is therefore known. According to Soerjono Soekanto, social interaction is an interpersonal exchange that each person demonstrates to conduct one another in their presence, and each behavior affects each other. ${ }^{7}$

In line with Soerjono Seokanto, Walgito defines social interactions as a relationship between individuals who influence other individuals or vice versa, so there is a reciprocal relationship. The relationships can occur

Terorisme: Humanis, Soul Approach dan Menyentuh Akar Rumput (Jakarta: Yayasan Pengembangan Kajian Ilmu Kepolisian, 2010), 144

6 Nur Salim dan Agus Widodo, "Pencegahan Paham Radikalisme dan Terorisme Melalui Pendidikan Multikulturalisme pada Siswa MAN Kediri I," Jurnal Abdinus 2, no. 1 (2018): 9. Iwan Satriawan, Muhammad Nur Islami, dan Tanto Lailam, "Pencegahan Gerakan Radikalisme melalui Penanaman Ideologi Pancasila dan Budaya Sadar Konstitusi Berbasis Komunitas," Jurnal Surya Masyarakat 1, no. 2 (28 Mei 2019): 99, https://doi.org/10.26714/jsm.1.2.2019.99-110. Raden Mas Jerry Indrawan, "Bela Negara sebagai Metode Pencegahan Ancaman Radikalisme di Indonesia," Jurnal Pertahanan \& Bela Negara 7, no. 3 (2017): 1-17.

7 Indah Sri Rahayu, "Hubungan Interaksi Sosial dengan Komunikasi Interpersonal Siswa di SMP Negeri 22 Kabupaten Tebo" (Skripsi, Jambi, Universitas Jambi, 2018), 5. 
between individuals with individuals, individuals with groups or groups with groups. ${ }^{8}$

The interaction must be at least three elements, namely the Communicator (person who performs the communication), the recipient (the person who made the object or the target), and the information (material being used as communication or interaction). 9 Good social interaction is characterized by smooth communication and the similarity of meaning between the recipient and communicator.

According to Soerjono Soekanto social interaction occurs when the in communication has fulfilled two conditions. First, social contact. Social contact occurs when involving humans giving each other action and reaction. Social contact can take place through two forms, which are social contact directly (face to face) and indirectly (through intermediate media). Second, communication. Social contact alone has not quite established social interaction with others, still needed another condition, namely communication. With communication, it is hoped that others understand and understand the message conveyed in social contacts. Communication consists of two forms, namely using sign Language (nonverbal), and using words that contain common meaning (verbal). ${ }^{10}$

Communication as an important part of culture has a significant role in interacting activities among others. Almost every act of interaction requires a communication which can then be referred to as communicative interactions. In Dictionary great Bahasa Indonesia (KBBI), communicative has two meanings, namely in a state of mutual contact (easy to contact); and easy to understand (understandable). ${ }^{11}$ The concept of communicative social interactions puts each person as an individual with the same existence in an interaction. So that the interaction between the two will arise mutual understanding, ultimately the goal between parties will be achieved in the interaction.

8 Indrati Endang Mulyaningsih, "Pengaruh Interaksi Sosial Keluarga, Motivasi Belajar, dan Kemandirian Belajar terhadap Prestasi Belajar," Jurnal Pendidikan dan Kebudayaan 20, no. 4 (Desember 2014): 444.

9 "Etin Soilihatin dalam Ahmad Multazam, ‘Pengaruh Interaksi Sosial Guru dan Siswa dalam Pembelajaran Terhadap Akhlak Siswa SMP Islam Ngebruk Malang' (Skripsi, Malang, Universitas Islam Negeri Maulana Malik Ibrahim, 2015), $19, "$ t.t.

${ }^{10}$ Effendy Onong Uchjana, Hubungan Masyarakat: Suatu Studi Komunikologis (Bandung: Remaja Rosdakarya, 1998), 109.

11 "Kamus Besar Bahasa Indonesia (KBBI) Kamus versi online/daring (dalam jaringan)," KBBI Web (blog), 2019, https://kbbi.web.id/komunikatif. 
An interhuman relationship is not merely a relationship between me and you, but it is essentially a relationship between me and me. The interhuman relationship is an essential and authentic meeting between two people who accept each other as a person who is intact and appreciates each other. ${ }^{12}$ Therefore, the relationship between human beings is a relationship that does not consider the difference in social status, such as education, derivatives, origins, ethnicity, etc.

Relationships between individuals are possible because the individual interacts with the other individual. Through interactions, individuals know each other, understand, dive in, and ultimately appreciate other individuals to develop their individuality. That interaction then allows individuals to develop communication. Communication is unlikely to take place without interaction. ${ }^{13}$ Collaboration between communications in an interaction forms a more powerful communicative social interaction in the development of individual qualities.

\section{The Urgency of Communicative Social Interactions}

According to Warren and Roucech, social interaction is a process of conveying reality, beliefs, attitudes, emotional reactions, and other consciousness of his neighbor in life. ${ }^{14}$ Based on this theory it is understandable that social interactions are one way for individuals to nurture their social behavior so that they can behave socially with other individuals. Social interactions can also increase the quantity and quality of individual social behaviors so that individuals become increasingly mature in acting with other individuals in the social environment.

On the other hand, communication has significance in the process of social interaction. In an interaction, a person gives a commentary on the behavior of another person who is like talking, an alarm or gesture, including what feelings the person wants to convey. The person in question then gives a reaction to the feelings that others want to convey. With such communication, the attitudes and feelings of a human or individual group

12 "Kleden Ignas, Intersubjektivitas Sebagai Gejala Kebudayaan (Jakarta: Leppenas, 1981), 25," t.t.

13 Vira Afriyati, "Strategi Orang Tua dalam Mengembangkan Interaksi Komunikatif dengan Anak Untuk Meningkatkan Kemampuan Membina Hubungan Sosial Anak," dalam Seminar Nasional BK FKIPUNIB (Profesionalisme Konselor Menghadapi Era Globalisasi, Bengkulu: Bimbingan dan Kosnseling FKIP Universitas Bengkulu, 2016), 212.

14 Slamet Santosa, Dinamika Kelompok (Jakarta: Bumi Aksara, 2004), 10. 
can be known by other groups or others. It is then a material to determine what reaction it does. 15

Communicative social interactions are necessary for a peer individual in the context of community life. The intrinsic and personal relationship between each other will result in a life of a common person collecting several private people. Life with a human being or more commonly called a society must be built and constructed while still taking into account the personal. Because society consists of individuals who have their characteristics. About this, Berdayev says that people should live in a community environment that does not mean that as an individual, he must be part of his community, because personality can never be a part of anything, too. Conclude that human beings do not have to be fully formed and determined by the people, but the people are formed and determined by private. The weight of a society is determined by the value of the individuals who support and form it. 16

Furthermore, the pattern of communicative social interaction between individuals and groups is also used as a solution to the occurrence of communication problems in a community. In a book titled Communicative Action Theory, Jurgen Habermas is craving a communicative action that has the power to unite society. Habermas remains consistent with its basic thesis that society can only be integrated through communicative action. He has a strong belief that the risk of considerable conflicts of interest can be dammed through public communication that produces legitimacy laws. For example, the theory of deliberative democracy is an attempt to reconstruct the process of communication in the context of a democratic legal state. ${ }^{17}$ The concept can also be applied to Indonesia's plural society, which is more likely to conflict of interest.

15 Rahmat Ayyub, "Interaksi Sosial dalam Dunia Maya (Fenomenologi Cyber Tumming dan Abu Youtubers Makassar)" (Skripsi, Makassar, Universitas Islam Negeri Alauddin, 2017), 20.

16 Afriyati, "Strategi Orang Tua dalam Mengembangkan Interaksi Komunikatif dengan Anak Untuk Meningkatkan Kemampuan Membina Hubungan Sosial Anak," 212.

17 Dismas Kwirinus, "Menuju Masyarakat Komunikatif menurut Jurgen Habermas," LSF Discourse (blog), 2019, https://lsfdiscourse.org/menujumasyarakat-komunikatif-menurut-jurgen-habermas/. 


\section{Method}

This article is a study of interactive communication among students as one of the efforts to prevent radical understanding in universities. This study is a psychological conceptual review. The main source of data search is the literature in the form of research results from various articles and books of scientific works collected with documentation techniques.

The collected data is analyzed by the content analysis method. This method performed by integrating several concepts and keywords to do inference-inference about its context. 18 Further, the accumulated data are categorized according to specific themes and patterns. The categories formulated based on records of existing data. This analysis pattern in the qualitative study uses inductive reasoning to conclude an objective and accountable study, both substantively and methodological.

\section{Finding and discussion}

\section{Radical Islam among students}

The word "radical" comes from the Latin, namely: radix which means root, where the meaning is a very deep thought to something until its roots. ${ }^{19}$ In the Great Dictionary of Bahasa Indonesia, the radical has three meanings, namely fundamentally (up to the principle thing); strictly demanding changes (laws, government); and forward in thinking or acting. ${ }^{20}$ Usually, radicalism is defined as a state political understanding that demands a change and a major overhaul as a way to achieve the level of progress. ${ }^{21}$ Based on that understanding, it can be understood that radicals must not have a negative connotation.

18 "Klaus Krippendorff, Content Analysis; an Indtroduction to Its Methodology (London: Sage Publication, 2004).," t.t.

19 Agus Sediadi Tamtanus, "Pemikiran: Menetralisir Radikalisme di Perguruan Tinggi Melalui Para Dosen," Untirta Civic Education Journal 3, no. 2 (Desember 2018): 211.

20 Ebta Setiawan, "Kamus Besar Bahasa Indonesia (KBBI) Kamus Versi Online/Daring (Dalam Jaringan)," KBBI Web (blog), 2019, https://kbbi.web.id/radikal.

21 Saifuddin, "Radikalisme Islam di Kalangan Mahasiswa (Sebuah Metamorfosa Baru)," ANALISIS: Jurnal Studi Keislaman 11, no. 1 (Juni 2011): 18. 
While Sartono Kartodirdjo reveals the term radicalism as a "social movement that functions to reject thoroughly the ongoing social order that is characterized by the aggregative of strong moral in opposition and hostile to people who have special and powerful privileges".22 In addition to radical terms, other designations are used to label a movement that tends to be the fundamentalist, extreme, and militant. The four terms are essentially directed at a person or group of people with pejorative, punishing, slaying, and degrading actions due to his radical, exclusive, enclosed, self-righteous, and absolute deeds in the face of a particular problem. ${ }^{23}$

Islam is one of the religions that have a close connection with radical movements. Azyumardi Azra in his book The Islamic political unrest of fundamentalism, modernism to Post-Modernism described the radical movements of Islam. He described it from the historical aspects, doctrines, ideological roots, about jihad in both its concept and practice, to the birth of radicalism in politics that make in the acts of terrorism in local, regional and international. ${ }^{24}$

Radical Islamic groups understand Islam as a perfect and complete religion and pay attention to cultural authenticity. Islam is not a religion in the Western sense, but Islam is a perfect way of life that governs all aspects of human life. This understanding establishes a view of life that has always missed the implementation of Islamic aspects in every joint life, not only in the ritual aspect of worship alone. ${ }^{25}$ This also affects the establishment of an exclusive identity as a specific criterion for this group.

The radicalization process also reaches the campus, especially among University students. The director of setara-institute, Halili in his research said that there are 10 public universities (PTN) in Indonesia exposed to Islamic Islam radicalism. University of Indonesia (UI), Institut Teknologi Bandung (ITB), University of Gajah Mada (UGM), State University Yogyakarta (UNY), UIN Jakarta, UIN Bandung, Bogor Agricultural Institute (IPB), Universitas Brawijaya (UNBRAW), university Matram UNIRAM, and Airlangga University (UNAIR). He also said the wave of radicalism at 10 PTN was carried by the exclusive religious group name from the group Salafi-Wahabi, Tarbiyah, and Tahririyah.

22 Sartono Kartodirdjo, Ratu Adil (Jakarta: Sinar Harapan, 1985), 38.

23 Buchor dalam Abdulloh Hadziq, "Nasionalisme Organisasi Mahasiswa Islam dalam Menangkal Radikalisme di Institut Agama Islam Negeri (IAIN) Surakarta," Jurnal Pendidikan Agama Islam Al-Thariqah 4, no. 1 (Juni 2019): 54.

24 Azyumardi Azra dalam Saifuddin, "Radikalisme Islam di Kalangan Mahasiswa (Sebuah Metamorfosa Baru)," 23.

25 Emna Laisa, "Islam dan Radikalisme," Islamuna 1, no. 1 (2014): 5. 
The pattern of Islamic activities on the campus exposed to radicalism is monolithic. These activities tend to be co-opted by certain closed or inclusive Islamists. The exclusive religious group gave birth to a discourse that its truthfulness is believed. In general, the discourse developed is to cling to the Qur'an, "Islam persecuted", and "Islam must be vigilant". They only believe they are learning and tend to be vigilant with a different thought, "he said. This religious group made mosques and Prayer room as a base of cauterization and targeted student organizations such as the Institute of Student Da'wah and faculty Da'wah Institute. ${ }^{26}$

Indications of high potential radicalism in the college environment can be seen from the level of support for radical movements in the state of Pancasila. Research from the FISIP of Brawijaya University in 2018 stated that about 23 percent of students in this university support and accept if there is a specific group implementing the Islamiyah Caliphate. One of the researchers revealed students become radical group targets because they are considered capable of building a support base, have skills and knowledge-especially engineering science or field of engineering as well as a group whose mental thinking is still giddy.27

\section{Communicative social interactions as an attempt to fortify students from radical Islam}

Behind the potential of radical spreading, the college has an important and strategic role in counteracting the dangers of radicalism and intolerance that grows in society. Students are expected to be spearheading to counteract the growing rise of radicalism to overcome the movement of radicalism. Ulul Huda in his research formulated the strategy undertaken by the campus to ward off radicalism in the higher education environment. First, preserve the Islamic activities that are full of peace, cool, and caring for each other. Secondly, it provides more student activities by enhancing talent and ability through sports, research, and self-development. Thirdly, supervision by the head society of academicians on campus facilities, mosques, prayer rooms, and meeting rooms. Fourth, we need to restrengthen the courses that have links to national strengthening. For

26 Alfian Putra Abdi, "Setara Institute Sebut 10 Kampus Terpapar Paham Radikalisme," Tirto.id (blog), 2019, https://tirto.id/setara-institute-sebut-10kampus-terpapar-paham-radikalisme-d9nh.

27 Nurika Manan, "Mengenali Pintu Masuk Radikalisme di Perguruan Tinggi," KBR.id (blog), 2019, https://kbr.id/nasional/06-2019/mengenali-pintumasuk-radikalisme-di-perguruan-tinggi/99439.html. 
example, Islamic religion, Pancasila, citizenship, history, and social sciences must be strengthened by the national context. 28

In line with the previous statement, students who are subject and central to the prevention of radical understanding. Thus, social interaction among students becomes very urgent and relevant. A conscious or unconscious student's social interaction is led by a system of knowledge, and an experience that will form a pattern of thinking about the attitudes he or she will bring in associating or interacting. The knowledge system is part of the culture that is the unity of the ideas and ideas that exist in the human head, containing a series of values and norms, including what are permissible and forbidden. The emergence of radicalism among students is based on self-understanding and negative interactions. As it is known at first the radical attitude grows within them as it arises a very dominant perception that they have been treated unfairly and oppressed so that it can be implanted heartache towards the person or the other party.

Social interaction is a common form of the social process, the form of interaction will be seen when the people of the human group have relationships with each other. The Association of individuals is a mere person, and will not produce social associations. Such a new life will happen when individuals or groups of people work together, conduct competition, strife, and assimilation, or debauchery. ${ }^{29}$ Positive interactions will prevent discontentment, anarchism, and radicalism. Communication must be open and communicative, to effectively prevent extreme actions. ${ }^{30}$ However, the presence of communicative interpersonal interactions will prevent negative acts, especially violence. ${ }^{31}$

In his position as a social creature, a student as a human tends to always relate to the environment. Firth suggests social interactions are always preceded by social contact and communication. Social contact may

28 Ulul Huda, Tenang Haryanto, dan Budiman Setyo Haryanto, "Strategi Penanggulangan Radikalisme di Perguruan Tinggi Kabupaten Banyumas," dalam Pengembangan Sumber Daya Perdesaan dan Kearifan Lokal Berkelanjutan, vol. VIII (Rekayasa Sosial dan Pengembangan Perdesaan, Purwokerto: LPPM Universitas Soedirman, 2018), 551.

${ }^{29}$ Soerjono Soekanto, Sosiologi Suatu Pengantar (Jakarta: Rajawali, 1986), 47.

30 Stefan Kitzmann, Prevention of Violent Extremism through Social Inclusion Social Impact Analysis of Eurodiaconia members' work (Heidelberg: Eurodiaconia, 2018).

31 Lebih lanjut baca Rini Rinawati dan Dedeh Fardiah, "Efektifitas Komunikasi Antarpribadi Dalam Mencegah Tindak Kekerasan Terhadap Anak," Jurnal Penelitian Komunikasi 19, no. 1 (29 Juli 2016): 29-40, https://doi.org/10.20422/jpk.v19i1.49. 
occur in the form of 1) between individuals, 2) between individuals and human groups, 3) among fellow groups. The communicative form of interaction will form a positive personal and otherwise negative interactions will form a destructive personal. 32

Interactions are a two-way process in which each individual or group stimulates another and in varying degrees modifies the participants ' behavior. The characteristic behavior and personality of individual members in a group affects the behavior of others and makes a significant impact on the function of a group as a whole. Each individual's behavior is influenced by other individual behaviors. This is known as the interaction process and it is the essence of social life. This is known as a driving factor that constructive social interactions can prevent the destructive action of a group.

Forms of social interaction among students include cooperation, competition and can even form a conflict, could also be an accommodation where disagreement may be a settlement that is only accepted for a while, it is mean the parties who are conflict not necessarily satisfied fully. ${ }^{33}$

In continuity, social interactions can be positive and negative forms. Negative forms, such as opposition or competition, are positive forms that can lead to cooperation. Indeed, a negative form of interaction in social life is natural. Because a group has a competitive and cooperative sense. For that social interaction, the most important is the extent to which the individual student is concerned or the group understands itself. There are two possibilities, namely as passive recipients in conjunction with a particular challenge, or as an active participator in the interaction. Even the extent to which they sought to change his attitude, control himself over his social environment, influence each other and their responsibilities to maintain the order.

Along with the creation of interaction, conditions also create an integration in the community. In this case, the separate groups (the culture, the norm) obliterate the differences that existed before. Besides, it can also be interpreted as an individual's acceptance by other members of a group.

32 Roderick Firth, "Are Epistemic Concepts Reducible to Ethical Concepts?," dalam Values and Morals, 13 (Dordrecht: D. Reidel, 1978), 56.

${ }^{33}$ Jens Allwood, "Cooperation, Competition, Conflict And Communication," 2007, 22; Baca juga Selo Soemardjan dan Soelaiman Soemardi, Setereotip Etnik, Asimilasi dan Integrasi Sosial (Jakarta: Fitaka, 1988), 77. 
Without adjustment, an open conflict, interference and violence will occur. ${ }^{34}$

In line with the views above Horton and Hunt presented two things that could hinder the occurrence of social interaction between the two group's namely social prejudice and discrimination. Social prejudice is a stated judgment before knowing the facts. This condition which becomes one of the causes of students will fall and enter into the movement of radicalism. This is exacerbated by the causes of the parties to blow up hostility and prejudice in the name of injustice. ${ }^{35}$ Prejudice is a negative evaluation of a social group or an individual's negative evaluation that is significantly based on individual group members. ${ }^{36}$

Several factors can encourage social interaction in the prevention of the emergence of radicalism among students as follows.

\section{a. Mutual Trust}

The patterns of interaction develop specially or distinctively. A person who carries out an interaction seeks to alter the characters they are not desired. On-campus, in interacting, lecturers try to change student attitudes that do not comply with the rules of norms and politeness. The trust factor is the most important. Glover, John A and Roger H Bruning suggest that from the first stage of interaction and interpersonal relationships to the second stage (the edification stage), "Believe" determine the effectiveness of communication. Scientifically, "Believe" is defined as "relying on the behavior of people to achieve the desired goal, whose achievement is uncertain and in a risk-filled situation". Loss of confidence in others will impede the development of intimate interactions and interpersonal relationships. Consequently, social interactions will not go smoothly so that all individuals involved in social interactions are willing to express their feelings and thoughts. Obviously, without believing it will grow communication failures. ${ }^{37}$

34 K.J. Veeger, Realitas Sosial, Refleksi Filsafat Sosial Atas Hubungan Individu Masyarakat Dalam Cakrawala Sejarah sosiolog (Jakarta: PT Gramedia Pustaka Utama, 1985), 73.

35 Paul B. Horton dan Chestr L Hunt, Sosiologi Jilid I (terjemahan Aminuddin Ram) (Jakarta: Erlangga, 1990), 91.

36 Christian S. Crandall dan Amy Eshleman, "The Justification-suppression Model of Prejudice: An Approach to the History of Prejudice Research," dalam Social Psychology of Prejudice: Historical and Contemporary Issues (Kansas: Lewinian Press, 1996), 237.

37 John A Glover dan Roger H. Bruning, Educational Psychology Principles and Applications (United States of America: Harper Collins Publishers, 1990). 
In addition to experience, three main factors can foster a trusting attitude or develop social and communication interactions based on mutual trust namely: accepting, empathy and honesty. ${ }^{38}$ Accepting is an attitude that sees others as human beings, as a valued individual while empathy is a growing stance on others. This honesty is very closely related to personal and personal ethics with the group. 39

\section{b. Sportive Attitude}

Sportive attitudes are attitudes that reduce defensive behavior in communication. People are defensive when he does not accept, dishonest, and not empathy. It is obvious, with the defensive attitude of interpersonal communication going to fail; because a defensive person will more protect themselves from the threats he responds in communication situations than to understand the message of others. Defensive communication can occur due to personal factors such as fear, anxiety, low self-esteem, defensive experience, and so on or can also be due to cryptosystem factors. Among these factors is the communication behavior of others. Gibb mentions six behaviors that pose sportive behavior namely, description, problem orientation, spontaneity, empathy, equality, and professionalism. 40

Sportive attitudes are indispensable in the social interaction of students. The sportsmanship that grows in social interment will encourage each student to appreciate each other and cultivate an attitude to be willing to acknowledge personal weakness and the strengths of others. High sportsmanship is also able to improve mutual togetherness and avoid students from fraudulent deeds.

\section{c. Discipline Attitude}

Discipline is a mental attitude that contains willingness to obey all provisions, rules and norms that apply in carrying out duties and obligations. Discipline is a process of practice related to growth and development. Discipline will not arise by itself. Discipline must be

38 Dominic D. Wells dan Anthony D. Molina, "The Truth About Honesty," Journal of Public and Nonprofit Affairs 3, no. 3 (1 Desember 2017): 292, https://doi.org/10.20899/jpna.3.3.292-308.

${ }^{39}$ Maaja Vadi dan Krista Jaakson, The Importance of Value Honest: Determining Factors and Some Hints to Ethics, Working Paper Series / University of Tartu, Faculty of Economics and Business Administration 43 (Tartu: Tartu Univ. Press, 2006).

40 Jack R. Gibb, "Defensive Communication," Journal of Communication 11, no. 3 (1 September 1961): 10-15, https://doi.org/10.1111/j.14602466.1961.tb00344.x. 
educated and implanted early. Discipline should be implemented with awareness. Thus discipline can be attached to the student so that the attitude and deeds done are no longer felt like a burden. Even when he did not discipline he felt guilty and felt there was a deficiency in him.

Discipline is indispensable for social interaction with others. The discipline that is embedded in students will encourage them to perform his responsibilities well. This discipline also encourages individual students to appreciate others in interacting and not violating the rights of others. Discipline is required in social interment as well as in the interaction of the required adherence of each individual to any agreed rule or provision. The attitude of discipline in social interaction, among others, is manifested through righteous conduct, does not violate the rights of others, comply with all the rules established by the school both in the form of a deed, and the other provisions (norms) that bind..$^{41}$

\section{d. Empathy}

Empathy can be interpreted as understanding the feelings and emotions of others. The ability to recognize the emotions of others or empathize is built on self-consciousness. If someone is open to his own emotions, he will be skilled at reading feelings. Empathize ability is useful to know how others feel. Being empathetic will continue to engage in moral considerations because moral dilemmas involve potential victims. Empathy is much related to caring. ${ }^{42}$ Empathy underlies many facets of moral action and considerations. Empathy is needed in relationship coaching and better social interactions. The skill of building relationships with others is a social skill that supports success in association with others. The ability of social interactions allows one to form relationships to mobilize and influence others, encourage a close relationship, convince and influence, and make others feel comfortable. Components of inter-personal intelligence: organizing groups, discussing problem-solving, personal relationships, and social analysis. ${ }^{43}$

Based on the above, it is obvious that communicative social interactions will have a positive impact on each individual as well as a

${ }^{41}$ J.B. Conant, General Education in a Free Society (Massachusetts: Harvard University Press, 1950).

42 Faye Miller, "Social Interaction and the Role of Empathy in Information and Knowledge Management: A Literature Review," Journal of Education for Library and Information Science 52, no. 2 (2011): 122.

${ }^{43}$ Calvin Hall dan Gardner Lindzey, Theories of Personality (USA: Wm. C. Brown Company Publishers, 1978). 
group. The existence of acceptance, honesty, empathy, and discipline will make every individual as a member of the group can share and support each other and control it to act positively. Thus it will be an effective Sara for the individual to avoid falling into negative thoughts and actions. In the context of combating understanding and the action of radicalism, it can be an effective means of preventing.

For social interaction to be effective to prevent radical Islam, social interaction must be built between students, students with lecturers, students with educational personnel and another academic school of campus and with the environment in which students reside. It is not only in the classroom but also outside the classroom. Not only in the campus environment but also outside the campus. ${ }^{4}$

\section{E. Conclusion}

Social interactions as an individual way to maintain social behavior can still behave socially with other individuals can increase the quantity and quality of individual social behavior. Communicative social interactions can make a person more mature in with other individuals in the social environment.

Social interactions are indispensable in student life as individuals and members of the community to communicate and assist each other and cooperate in achieving the desired common goals. Positive social interactions can be an antidote to religious understanding among closed and textual students, so they feel as a group that feels most understanding of God's teachings. Therefore, there needs to having better knowledge and understanding of religion for students and strive to accomplish harmonious and communicative social interaction so that students can avoid and be prevented from understanding religious-based radicals and become a figure that has a high social concern.

44 Bandingkan dengan Zulfani Sesmiarni, "Membendung Radikalisme dalam Dunia Pendidikan Melalui Pendekatan Brain Based Learning," KALAM 9, no. 2 (23 Februari 2017): 245-50, https:/ / doi.org/10.24042/klm.v9i2.330. 


\section{REFERENCES}

Afriyati, Vira. "Strategi Orang Tua Dalam Mengembangkan Interaksi Komunikatif Dengan Anak Untuk Meningkatkan Kemampuan Membina Hubungan Sosial Anak." Dalam Seminar Nasional BK FKIPUNIB. Bengkulu: Bimbingan Dan Kosnseling FKIP Universitas Bengkulu, 2016.

Allwood, Jens. "Cooperation, Competition, Conflict And Communication," 2007, 22.

Ayyub, Rahmat. "Interaksi Sosial Dalam Dunia Maya (Fenomenologi Cyber Tumming Dan Abu Youtubers Makassar)." Skripsi, Universitas Islam Negeri Alauddin, 2017.

Conant, J.B. General Education In A Free Society. Massachusetts: Harvard University Press, 1950.

Crandall, Christian S., Dan Amy Eshleman. “The Justification-Suppression Model Of Prejudice: An Approach To The History Of Prejudice Research." Dalam Social Psychology Of Prejudice: Historical And Contemporary Issues. Kansas: Lewinian Press, 1996.

“Etin Soilihatin Dalam Ahmad Multazam, 'Pengaruh Interaksi Sosial Guru Dan Siswa Dalam Pembelajaran Terhadap Akhlak Siswa SMP Islam Ngebruk Malang' (Skripsi, Malang, Universitas Islam Negeri Maulana Malik Ibrahim, 2015), 19," T.T.

Firth, Roderick. "Are Epistemic Concepts Reducible To Ethical Concepts?" Dalam Values And Morals. 13. Dordrecht: D. Reidel, 1978.

Gibb, Jack R. "Defensive Communication." Journal Of Communication 11, No. 3 (1 September 1961): 141-48. Https://Doi.Org/10.1111/J.14602466.1961.Tb00344.X.

Glover, John A, Dan Roger H. Bruning. Educational Psychology Principles And Applications. United States Of America: Harper Collins Publishers, 1990.

Hadziq, Abdulloh. "Nasionalisme Organisasi Mahasiswa Islam Dalam Menangkal Radikalisme Di Institut Agama Islam Negeri (IAIN) Surakarta." Jurnal Pendidikan Agama Islam Al-Thariqah 4, No. 1 (Juni 2019).

Hall, Calvin, Dan Gardner Lindzey. Theories Of Personality. USA: Wm. C. Brown Company Publishers, 1978.

Horton, Paul B., Dan Chestr L Hunt. Sosiologi Jilid I (Terjemahan Aminuddin Ram). Jakarta: Erlangga, 1990.

Huda, Ulul, Tenang Haryanto, Dan Budiman Setyo Haryanto. "Strategi Penanggulangan Radikalisme Di Perguruan Tinggi Kabupaten Banyumas." Dalam Pengembangan Sumber Daya Perdesaan Dan Kearifan 
Lokal Berkelanjutan, Vol. VIII. Purwokerto: LPPM Universitas Soedirman, 2018.

Indrawan, Raden Mas Jerry. "Bela Negara Sebagai Metode Pencegahan Ancaman Radikalisme Di Indonesia." Jurnal Pertahanan \& Bela Negara 7, No. 3 (2017): 1-17.

KBBI Web. "Kamus Besar Bahasa Indonesia (KBBI) Kamus Versi Online/Daring (Dalam Jaringan)," 2019. Https://Kbbi.Web.Id/Komunikatif.

Kartodirdjo, Sartono. Ratu Adil. Jakarta: Sinar Harapan, 1985.

Kitzmann, Stefan. Prevention Of Violent Extremism Through Social Inclusion Social Impact Analysis Of Eurodiaconia Members' Work. Heidelberg: Eurodiaconia, 2018.

"Klaus Krippendorff, Content Analysis; An Indtroduction To Its Methodology (London: Sage Publication, 2004).," T.T.

"Kleden Ignas, Intersubjektivitas Sebagai Gejala Kebudayaan (Jakarta: Leppenas, 1981), 25," T.T.

Kruglanski, Arie W., Michele J. Gelfand, Jocelyn J. Bélanger, Anna Sheveland, Malkanthi Hetiarachchi, Dan Rohan Gunaratna. "The Psychology Of Radicalization And Deradicalization: How Significance Quest Impacts Violent Extremism: Processes Of Radicalization And Deradicalization." Political Psychology 35 (Februari 2014): 69-93. Https://Doi.Org/10.1111/Pops.12163.

Kwirinus, Dismas. "Menuju Masyarakat Komunikatif Menurut Jurgen Habermas." LSF Discourse (Blog), 2019.

Https://Lsfdiscourse.Org/Menuju-Masyarakat-Komunikatif-

Menurut-Jurgen-Habermas/.

Laisa, Emna. "Islam Dan Radikalisme." Islamuna 1, No. 1 (2014).

Manan, Nurika. "Mengenali Pintu Masuk Radikalisme Di Perguruan Tinggi." KBR.Id (Blog), 2019. Https://Kbr.Id/Nasional/062019/Mengenali-Pintu-Masuk-Radikalisme-Di-Perguruan-

Tinggi/99439.Html.

Miller, Faye. "Social Interaction And The Role Of Empathy In Information And Knowledge Management: A Literature Review." Journal Of Education For Library And Information Science 52, No. 2 (2011).

Mulyaningsih, Indrati Endang. "Pengaruh Interaksi Sosial Keluarga, Motivasi Belajar, Dan Kemandirian Belajar Terhadap Prestasi Belajar." Jurnal Pendidikan Dan Kebudayaan 20, No. 4 (Desember 2014). Rahayu, Indah Sri. "Hubungan Interaksi Sosial Dengan Komunikasi Interpersonal Siswa Di SMP Negeri 22 Kabupaten Tebo." Skripsi, Universitas Jambi, 2018. 
Rinawati, Rini, Dan Dedeh Fardiah. "Efektifitas Komunikasi Antarpribadi Dalam Mencegah Tindak Kekerasan Terhadap Anak." Jurnal Penelitian Komunikasi 19, No. 1 (29 Juli 2016): 29-40. Https://Doi.Org/10.20422/Jpk.V19i1.49.

Rokhmad, Abu. "Radikalisme Islam Dan Upaya Deradikalisasi Paham Radikal." Walisongo: Jurnal Penelitian Sosial Keagamaan 20, No. 1 (30 Mei 2012): 79. Https://Doi.Org/10.21580/Ws.20.1.185.

Saifuddin. "Radikalisme Islam Di Kalangan Mahasiswa (Sebuah Metamorfosa Baru)." ANALISIS: Jurnal Studi Keislaman 11, No. 1 (Juni 2011).

Salim, Nur, Dan Agus Widodo. "Pencegahan Paham Radikalisme Dan Terorisme Melalui Pendidikan Multikulturalisme Pada Siswa MAN Kediri I." Jurnal Abdinus 2, No. 1 (2018): 9.

Santosa, Slamet. Dinamika Kelompok. Jakarta: Bumi Aksara, 2004.

Sesmiarni, Zulfani. "Membendung Radikalisme Dalam Dunia Pendidikan

Melalui Pendekatan Brain Based Learning." KALAM 9, No. 2 (23 Februari 2017): 233. Https:/ / Doi.Org/10.24042/Klm.V9i2.330.

Setiawan, Ebta. "Kamus Besar Bahasa Indonesia (KBBI) Kamus Versi Online/Daring (Dalam Jaringan)." KBBI Web (Blog), 2019. Https:/ / Kbbi.Web.Id/Radikal.

Soekanto, Soerjono. Sosiologi Suatu Pengantar. Jakarta: Rajawali, 1986.

Soemardjan, Selo, Dan Soelaiman Soemardi. Setereotip Etnik, Asimilasi Dan Integrasi Sosial. Jakarta: Fitaka, 1988.

Tamtanus, Agus Sediadi. "Pemikiran: Menetralisir Radikalisme Di Perguruan Tinggi Melalui Para Dosen." Untirta Civic Education Journal 3, No. 2 (Desember 2018).

Uchjana, Effendy Onong. Hubungan Masyarakat: Suatu Studi Komunikologis. Bandung: Remaja Rosdakarya, 1998.

Vadi, Maaja, Dan Krista Jaakson. The Importance Of Value Honest: Determining Factors And Some Hints To Ethics. Working Paper Series / University Of Tartu, Faculty Of Economics And Business Administration 43. Tartu: Tartu Univ. Press, 2006.

Veeger, K.J. Realitas Sosial, Refleksi Filsafat Sosial Atas Hubungan Individu Masyarakat Dalam Cakrawala Sejarah Sosiolog. Jakarta: PT Gramedia Pustaka Utama, 1985.

Wells, Dominic D., Dan Anthony D. Molina. "The Truth About Honesty." Journal Of Public And Nonprofit Affairs 3, No. 3 (1 Desember 2017): 292. Https://Doi.Org/10.20899/Jpna.3.3.292-308. 